\title{
The establishment of Community Governance Structure of Deliberative Democracy
}

\author{
Xifang Wang \\ School of Management, \\ Xi'an University Of Architecture And Technology \\ Xi'an, Shaanxi, China \\ 38740191@qq.comLogistics Office
}

\author{
Zhenzhou Wang \\ Logistics Office \\ Sichuan Institute of socialism \\ Chengdu,Sichuan, China \\ zhenzhou32@163.com
}

\begin{abstract}
As the basic unit of city, community governance emphasizes the process of governance and the cooperative interaction among the governance subjects, they need to deliberate the community public affairs on the base of democracy. Aithough there are problems with community governance subjects such as unknown positioning, lack of participation and other "absence", "misplaced" issue, affecting the community governance effect, we still can bulid a platform of deliberative democracy, which make all subjects take the public interest as the main community guidelines, straightening out relations, cooperate, and ultimately to achieve community development.
\end{abstract}

Keywords: Deliberative democracy; community governance; government structure; government subjects; goverment platform

\section{INTRODUCTION}

In 30 years, as the basic unit of city, communities gradually got into the public view, and attrcted more and more attention. The government and academia are increasing emphasis on the urban community. At the theoretical level, it triggered a burgeoning community study, and at the policy level, there are so many documents and files about urban communities issued from the central to local goverments.[1] At the same time, many cities try to lanch the communities system institutional reform and exploration as a practice. All these attemps have face to the same questiong that how to integrate variety subjects in community, and which has become the foundation of community governance.

Deliberative democracy theory. The theory is a new focus of Western academics in the late 20th century. Western scholars believe that the elements of representative democracy has been incompatible with the modern demands of citizens and social development, and citizens and government need directly face to face dialogue and discuss on common policy issues related to public advantages, which has become the one of the most basic elements of political democracy, can not be replaced in any other way. They actively promote the directly political participation of citizens, and believe that deliberative democracy is democracy direction of development, is the core of contemporary democracy. [2] American political philosopher John Rawls, the famous British social and political theorist Anthony Giddens, German thought leaders Jugen Habermas and others are all active advocate of deliberative democracy.After
Deliberative democracy theory introduced to China, the Chinese academia believe its consistent with China's political consultation system, but is not limited to political consultation. [3] Used in practice throughout the democratic association, democratic hearings, residents forum, even inquire politics in networks, all these variety forms belong to the scope of deliberative democracy.

community governance. Community governance means that on the premise of legalization and standardization, administrative organization, community party organizations and community autonomy organizations, community non-profit organizations, district companys, community residents and other multivariate subjects joint management of community public affairs. [4] According to the definition of community governance has the following main characteristics of plural subjects, largescale range and process-emphasis. Community governance is the usage of the governmence theory originated in the west in the 20th century, emphasizing cooperation and interaction among the governance subjects, paying attention to the community co-management of public affairs process.Since the 1950 s, along with the economic reform and social transformation, Chinese city administration has adopted three kind of systems. The first one is the system of units supplemented by residents committee system, the second one is residents committee system supplemented by units system, and now all the cities adopt community system. The domestic scholars believe that the basic principles of governance theory is suitable for the current urban community, proposed the concept of "community governance", and some cities have used the word "community governance" as document title.

Community governance subjects. In accordance with governance theory and the practice of community governance, community governance subjects including community residents, the owners' committee, community CCP organizations, Residents Committee, government organizations, property companies, social organizations. Among them, the owners' committee typically limited to a commercial housing district. In practice, a large scale commercial housing district can be used alone as a community, but most communities contain several or dozens of residential areas. Governmental organizations include district offices and community service stations, and community service stations are generally undertake an extension of government functions as a community level institutions. Social organization is composed of the 
community residents or other people to work in the community, which include profit organizations and nonprofit organizations.In accordance with its role in governance of public affairs in the community, these subjects can be divided into the theory subjects and practice subjects. [5]The theory subjects is from the value of community governance needs, including all community stakeholders in public affairs, while the practice subject is those actually involved in community public affairs governance.

\section{COMMUNITY GOVERNANCE SUBJECTS DILEMMA}

According to China's current laws and regulations, the relationship among the subjects can be represented by figure1:

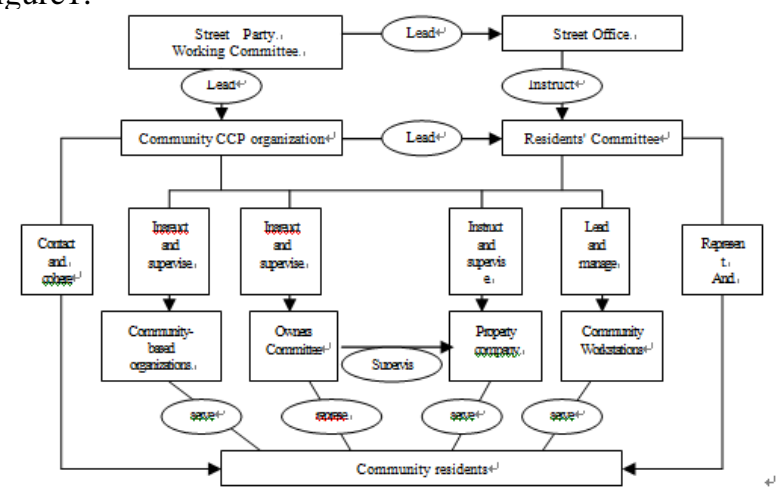

Figure 1: The relationship between community governance body

\section{A. Community residents "few participation."}

Community residents is the basis for community governance, the residents pay very important role in community development throug caring about and paticipating in the public affairs. In reality, rapid urbanization has led to intense strangeness among the residents of the community, the sense of identity and belonging is on the low presence in the community. Moreover, most of the residents have "free rider" mentality on public affairs. And during the long-term units system, the units arranged all the public affairs of their staff and family members, so people are used to be passive participationer rather than proactive participationer. Overall, community residents have high enthusiasm for literature, art and sports activities, while less political participation; greater participation of older people, while young people participate less; more participation in activities involved material interests, while less participation in unprofitable activity.

\section{B. The difficult participation of owners' committee.}

As representative organization of the interests of owners, the owners committee appears to solve the contradiction between residents and property company. According the law, the owners' committee is elected voluntarily by the owners in the light of the legal procedures, and it is on behalf of the owners profits, exercising their powers. [6]In practice, the owners' committee just pay limited role in public affairs, and there are three common reasons: the first is that the law don't give clear directions about the legal status of the owners' committee work and how it works; the second is that the owners' committee can't be support by owners, the residents' committee or street office; the third is that some of the owners' committee members take it as a platform to seek personal interests from the property company, and departed from the organization's mission.

\section{The absence of community CCP organizations.}

As the Chinese Communist Party's grassroots organizations, community CCP organizations should be the core of community governance subjects, pay strong leadership and coordination role, consolidate community resources to promote community development. In practice, since the community $\mathrm{CCP}$ organizations mainly registered retired members and scattered members don't belong to any unit, and the registered party members' average age is from 60 years old to 70 years old, these party members and their CCP organization is difficult to play the role of connectiong and mobilizing the masses. And various community other units $\mathrm{CCP}$ organizations have no platform of cooperation, so they few participate in community public affairs. In fact, the community CCP organizations can not play a grass-roots party's role of integration and cohesion.

\section{The dislocation of Residents' Committee.}

According the law, the residents' committee is an autonomous organization of community residents, but in practice, it seems to be a kind of administrative organization. At present, senior $\mathrm{CCP}$ and government organizations extend many work to the residents' committee. According to rough statistics, there are more than more than 10 categories and 100 items work transfered to the residents' committee, and superiors take the annual assessment of the implementation of these tasks and give rewards. However, the residents' committee has only 5-9 staff members, and most of them are high average age, low knowledge level and wages. The residents' committee manages several thousand households, complete the various transfered tasks, which make them struggle to cope with faction, and no time to take the autonomous functions into account.

\section{E. The governmental organizations offside.}

Currently in the community, city governments promote "community workstations" as a platform, and provide residents with one-stop service for a variety of administrative affairs, for example Pension, health care, family planning, subsistence allowances and others. The purpose of establishment of community workstation is to separate government agency from the residents' committee, restore it's autonomy identity. In practice, city government promote that one person holds three positions including community CCP organization secretary, director of the residents' committee and the head of community workstation. In this way, the same person crossing the three organizations work, break up the system designed to separate the functions.

\section{F. Property company's unwilling participation.}

Property companies are businesses, operate in accordance with the laws of the market, and pursuit the interests. In commercial housing district, the property company responsible for the infrastructure, environment and security. However, these are not only an important assessment content of city management, but also key 
indicators in assessment of civilized city, clean city and the "harmonious community". However, who can control and supervise property companies? Owners Committee is difficult to do the job due to lack of legal support, moreover, many communities have not established the owners committee; residents' committees have no channels to supervise and control. And there is another policy that promote cross-tenure of the residents committee with the property company staff, which means that the property company staff can be residents members. In this way, suspicion and mistrust between residents and their autonomous organizations will be exacerbated because the antagonistic relationships between owners and property company.

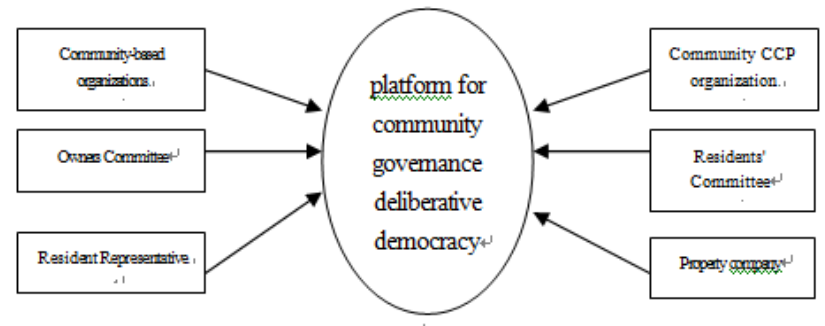

Figure 2: platform for community governance deliberative democracy

\section{G. Shallow participation of community organizations.}

The number and effect of social organizations reflect the degree of modernization of a society. In recent years, our country attaches great importance to fostering social organization. According to official statistics, as of June 2011, China formally registered 450,000 social organizations, community organizations filed 250,000, the actual existence of the three million or so. Average annual growth rate of $8-10 \%$. These organizations covering almost all aspects of society: science and technology, education, culture, health, labor, civil affairs, sports, the environment, law, charitable and other public areas and intermediaries, business services, the initial formation system. However, in most of the communities, only one of the organizations is most active - literature and sports organizations. As for the other organizations, it is difficult to carry out the work. Due to community organizations actually are less amount and monotonous species, as a important community governance theory subjects, it is far from providing residents with a variety of public services.

Overall, due to the demands of the different interests, vague function and position, insufficient legal basis, the lack of consultation channels, every subject can not give full play in the role of community governmence. Which lead to the result that the practice subject is generally less than the theory subject in community governance. And the phenomenon of "government failure" and "community failure" is prevalence, the credibility, cohesion and influence of government and community is reduced in residents, community governance is difficult to form the main force.

\section{BUILD A PLATFORM FOR COMMUNITY GOVERNANCE DELIBERATIVE DEMOCRORACY}

According to the basic theory of deliberative democracy and democratic consultation system of practical experience, a platform for deliberative democracy should be explored and built to promote the subjects win-win cooperation. In this way, all subjects work together to community development, to achieve "orderly management, perfect service, civilized and peaceful" community governance objectives. In order to promote community governance, there are many cities reformed their district offices and community governance system, and some cities do subtraction, revocated street offices and established a large communities of street level; others do addition, increasing the functions and powers of street offices to promote the residents committees' autonomous activity; and some cities integrated all the community subjects as the deliberative organ, the decision-making bodies, executive agencies, oversight agencies. These explorations combined the reality of around to form a "Shanghai mode", "Wuhan mode", and "Shenyang mode."[7] In summary, no matter which model, it must focus on clear responsibilities and relationship among community governance subjects.

\section{A. The unwavering core status of community CCP organizations.}

Community CCP organizations need to strengthen organizations and to play a primary bastion role, in order to play cohesion, regulatory role in community governance. The way can be ideology to guide, the check on decisionmaking, the security in organization, the example in life, but not directly intervene in specific tasks. Based on the China's actual situation, deliberative democracy still requires a strong core of cohesion and integration of the main force, and on the whole Chinese society development, the Chinese Communist Party fomulate strategies, protect strategies implementation, and integrate of social resources, play the role of society governance.[8] In fact, the party's organizational network have been formated based on a system of social integration mechanisms. The community CCP organization shoud do effective integration and mobilization of community resources, to provide political guarantees and support community legal autonomy, which will be the best way to win the leadership and cohesion.

\section{B. The establishment of platform for community governance deliberative democracy.}

Take community CCP organizations as the core, a deliberative democracy platform should be established by which all subjects can participate in community governance. with this platform, the interests and aspirations of all subjects united in community development goals, and they can agree on the community public affairs.

The platform is not formalized. For example, the community CCP organizations can convene the community deliberative democratic meetings regularly or irregularly. Community governance information platform can be built based on the information technology, by which the community CCP organizations, residents committees, can disclose their work information, residents can take it as a channel to reflect demands or raised problems, and it also can be a feedback platform for the residents. [9]In summary, it provides opportunities for deliberative democratic, enhances responsiveness. Community governance Forum can be organized, which can encourage community governance body to express their views in public affairs, to make recommendations. If involving matters of public interest, community $\mathrm{CCP}$ organization can promptly convene a public earnest 
meeting, contradictory coordination meeting, affairs hearings, evaluation meetiong of effect and other forms, discuss the public affairs that residents focused on or involving the vital interests of residents, the main aim is to achieve positive interaction of cooperation among all subjects, avoid their non-rational game against the public interests of community.

\section{Straighten out the relationship among the subjects.}

Street offices should perform all their administrative duties responsibly, in addition to the law can be extended to community work, not temporary assessed. [10] Residents committee should return to the functions of autonomous organizations, represent and safeguard the interests of the community residents. Under the guidance of residents committee, the owners committee, on behalf of the owners instrests, oversight of property company. But the nature, status, responsibilities and job security of the owners committee are required to be further defined by the law. [11]Community CCP organizations and residents committees should carry out extensive scientific propaganda, public service and other activities, and strengthen supervision of community organizationsto ensure that they are normative in the process of providing paid services for the residents. Street offices should guide residents committee to enhance the quality of residents, and promote exchanges between the residents, harmonious neighborhood relations, foster community trust network and strengthen the sense of belonging.

\section{REFERENCE}

[1] Zheng hangsheng, Huang jialiang, The new trend of current China's social management and community governance[J], Gansu Social Sciences, 2012(6):1-8

[2] Gao Jian, Tong Tak Chi, Deliberative Democracy [M], 1st ed, Tianjin: Tianjin People's Publishing House, 2010.

[3] Zhang yangjin, Overview of Modern western deliberative democracy theory research[J], Theory Guide, 2008(1): 99-102.

[4] Qiumeng Hua, Urban Community Governance [M], 1st ed, Beijing: Tsinghua University Press, 2013.

[5] Li Haosheng, The main city community governance structure in the conflict and coordination[J], DongYue Tribune, 2011(12): 7679.

[6] The People's Net, The organization law of people's Republic of China cityresidents committee [EB/OL]. 2010-3-11. http: //www. people. com. cn/ item/ flfgk/rdlf/1989/111201198908.html

[7] Wang Fang, Li Hezhong, Realistic choice of city community governance model[J], Chinese administration,2008(4): 68-69.

[8] Zhao Xiaolei, Yao Xuelian, Community governance under the perspective of governance theory:Predicament and Path Choice $[\mathrm{J}]$ Journal of Dali University,2012(5):12-18.

[9] Chen Jingling, The responsibility of government in city community "good governance"[J], Ecological Economy,2008(10): 54-56.

[10] HuXiang, Study on the connotation of city community governance [J], Theory monthly, 2009(8)71-73.

[11] Mao Junquan, The owners of the Committee: Institutional consensus, in community governance autonomy predicament and action strategies[J], Journal of Lanzhou,2011(5): 13-18. 